$\int \mid$\begin{tabular}{c} 
JURNAL MEGA AKTIVA \\
Email : megaaktiva@febi.umkendari.ac.id \\
Website : https://megaaktiva.umkendari.ac.id/index.php/Jurnal \\
\hline
\end{tabular}

\title{
KEPUTUSAN PENDANAAN, UKURAN PERUSAHAAN, LABA PERUSAHAAN DAN RISK BASED CAPITAL, SEBAGAI VARIABEL PREDIKTOR NILAI PERUSAHAAN ASURANSI DI INDONESIA
}

\author{
${ }^{1}$ Adnan Hakim, ${ }^{2} \mathrm{Al}$ Asy Ari Adnan Hakim \\ ${ }^{1}$ Fakultas Ekonomi dan Bisnis, Universitas Halu Oleo (UHO) \\ Email : adnanhakim25@yahoo.co.id \\ ${ }^{2}$ Fakultas Ekonomi dan Bisnis Islam, Universitas Muhammadiyah Kendari \\ Email : arhyian@yahoo.co.id
}

\begin{abstract}
ABSTRACK
This research is to analyze and determine the contribution of factor funding decisions, the size of the company, the company's profit and risk based capital simultaneously and partially to the company's value. The approach used is The correlation between variables, while the sampling technique is purposive sampling were selected based on certain criteria as much as 10 insurance companies listed on the Jakarta Stock Exchange in parentheses period of 7 years. The data used is secondary data that is accessed from the JSE's website, and the methods of analysis used is multiple linear regression. The results of this study found that the funding decision does not significantly increase the value of the company, while the size of the company and the company's profit as well as partial risk-based capital has a positive and significant effect in increasing the value of the company. Then simultaneously discovered all the observed variables have contributed simultaneously to enhance shareholder value. This means that, to increase the value of the company, it needed the funding decision is effective and efficient, the size of the company and the company's profit and risk-based capital.
\end{abstract}

Keywords : Financing Decision, Company Size, Firm profit, Risk Based Capital, Corporate Value.

\section{PENDAHULUAN}

Di era perkembangan ilmu pengetahuan dan teknologi informasi seperti sekarang ini, telah membawa aneka perubahan dan situasi yang semakin kompleks sehingga dunia bisnis menghadapi tingkat persaingan yang semakin tajam dan sulit diprediksi keberadaannya. Salah satu misi pengelola usaha ketika mendirikan dan menjalanan usaha yaitu, agar usahanya dapat tumbuh dan berkembang serta memiliki daya saing yang kompetitif. Suatu usaha yang ingin sukses harus mempunyai orientasi pengembangan usaha dan tidak hanya bisa bermain dalam skala nasional tetapi harus dapat bermain dalam skala Internasional.

Perusahaan yang termotivasi untuk berbisnis dalam lingkungan persaingan yang kompetetif, mengharuskan usahanya untuk masuk dalam kegiatan pasar modal. Hanya saja untuk masuk bermain dipasar modal tentu banyak persyaratan yang harus dipenuhi, dan perusahaan yang dinyatakan terdaftar dipasar modal, berarti telah memenuhi semua ketentuan-ketentuan yang berlaku. Misalnya, mempublikasikan laporan keuangannya secara rutin setiap periode tertentu, agar calon investor mempunyai informasi tentang kesehatan keuangan perusahaan yang bersangkutan. 
Dengan membaca hasil laporan keuangan perusahaan yang telah dipublikasikan secara transparan akan dapat diperoleh gambaran tentang nilai perusahaan (firm value). Weston \& Copeland (1992) menyatakan bahwa, memaksimumkan nilai perusahaan disepakati sebagai tujuan bagi perusahaan, terutama yang berorientasi laba, sedangkan Sudana (2009:7) mengemukakan bahwa, nilai perusahaan tercermin dari harga saham yang stabil, yang dalam jangka panjang mengalami kenaikan, semakin tinggi harga saham maka semakin tinggi pula nilai perusahaan. Lebih lanjut dinyataan bahwa tujuan normatif perusahaan adalah memaksimumkan kekayaan pemegang saham.

Berdasarkan uraian tersebut maka dapat dikatakan bahwa, setiap perusahaan yang didirikan mempunyai tujuan jangka pendek, yaitu memaksimumkan laba, dan jangka panjang adalah memaksimumkan nilai perusahaan, yang tercermin dari harga pasar sahamnya, karena penilaian para investor terhadap perusahaan dapat diamati pergerakan harga saham perusahaan.

Perusahaan yang ingin mencapai tujuan jangka panjang secara efektif dan efisien akan mengambil beberapa keputusan keuangan berupa keputusan investasi, keputusan pembelanjaan dan kebijakan dividen (Husnan \& Pudjiastuti, 2006). Fama \& French (1998) menyatakan bahwa setiap keputusan keuangan yang diambil akan mempengaruhi keputusan keuangan lainnya dan berdampak terhadap nilai perusahaan.

Nilai perusahaan merupakan harga yang bersedia dibayar oleh calon pembeli apabila perusahaan tersebut dijual (Husnan, 1997), sedangkan Jomes Tobin dalam Lindenberg \& Ross (1981) menyatakan bahwa nilai perusahaan merupakan suatu proforma manajemen dalam mengelola aktiva perusahaan yang ditunjukkan dengan nilai Tobin's $g$. Peningkatan nilai perusahaan ternyata telah menjadi sasaran utama bagi pihak manajemen perusahaan untuk dicapai agar dapat memberikan kemakmuran bagi para pemegang saham perusahaan. Ini berarti semakin tinggi harga saham maka semakin tinggi pula nilai perusahaan.

Jadi nilai perusahaan yang tinggi mencerminkan tingkat kemakmuran pemegang saham yang tinggi pula. Untuk mencapai nilai perusahaan yang tinggi, maka manajer keuangan akan melakukan tindakan terbaik bagi perusahaan dengan memaksimalkan nilai perusahaan sehingga kemakmuran (kesejahteraan) pemilik atau pemegang saham dapat tercapai (Husnan, 2000:7).

Besar kecilnya nilai perusahaan sangat ditentukan oleh berbagai faktor, ada yang menyatakan bahwa faktor yang mempengaruhi nilai perusahaan yaitu keputusan pendanaan, kebijakan dividen, keputusan investasi, struktur modal, pertumbuhan perusahaan, ukuran perusahaan (Sartono, 2008:55). Faktor-faktor tersebut telah dikaji oleh beberapa peneliti terdahulu yang menemukan bahwa, keputusan pendanaan memiliki hubungan positif dengan nilai perusahaan (Gayatri \& Mustanda, 2013:10).

Ukuran perusahaan dinyatakan berhubungan positif dan signifikan terhadap nilai perusahaan (Siallagan \& Mas'ud, 2006:10; Rachmawati, dkk, 2007; Yunita, 2011), sedangkan Wiyono (2012) menemukan bahwa, nilai perusahaan dipengaruhi secara negative oleh ukuran perusahaan. Selanjutnya, Siallagan \& Mas'ud (2006) menemukan bahwa laba perusahan berpengaruh secara positif terhadap nilai perusahaan, hal ini menunjukkan bahwa pelaporan laba perusahaan dapat merefleksikan nilai perusahaan, jika perusahaan mengalami kerugian akan dapat menurunkan nilai perusahaan, sedangkan Yunita (2011) dan Mahendra (2011) menemukan bahwa profitabilitas berpengaruh positif terhadap nilai perusahaan. 
Wulandari (2011) menemukan bahwa ada pengaruh yang signifikan tingkat Risk Based Capital terhadap nilai perusahaan, sedangkan Kirmizi (2011) menemukan bahwa tidak ada pengaruh yang signifikan tingkat risk based capital terhadap nilai perusahaan. Dalam uraian tersebut diperoleh informasi bahwa nilai perusahaan sangat ditentukan oleh berbagai faktor, baik faktor kebijakan pendanaan, ukuran perusahaan, laba perusahaan dan risk based capital maupun faktor-faktor lainnya.

Faktor-faktor tersebut telah banyak dikaji oleh para peneliti, namun hasilnya bervariasi, ada yang menyatakan mempunyai hubungan positif dan signifikan dalam meningkatkan nilai perusahaan, dan juga yang menemukan justru sebaliknya. Hubungan antara faktor kebijakan pendanaan, ukuran perusahaan dan laba perusahaan serta risk base capital dengan nilai perusahaan, ingin pula diamati dilingkungan perusahaan asuransi yang terdaftar di Bursa Efek Jakarta.

\section{KAJIAN TEORI}

\section{Nilai Perusahaan}

Setiap usaha yang dibangun mempunyai beberapa tujuan, baik yang bersifat jangka pendek, misalnya memaksimumkan laba maupun tujuan jangka panjang adalah memaksimumkan nilai perusahaan. Weston \& Copeland (1992) menyatakan bahwa, memaksimumkan nilai perusahaan disepakati sebagai tujuan bagi perusahaan, terutama yang berorientasi laba, sedangkan Sartono (2008:55), menyatakan tujuan utama perusahaan adalah untuk meningkatkan nilai perusahaan melalui peningkatan kemakmuran pemilik atau para pemegang saham.

Nilai perusahaan merupakan nilai yang dibutuhkan investor dalam mengambil keputusan investasi yang tercermin dari harga pasar perusahaan (Husnan, 2006), sedangkan Fama (1998:6) menyatakan bahwa, nilai perusahaan akan tercermin dari harga sahamnya.

Menurut Husnan (2001) bahwa nilai perusahaan merupakan harga yang bersedia dibayar oleh calon pembeli apabila perusahaan tersebut dijual. Kemudian Jomes Tobin dalam Lindenberg \& Ross (1981) menyatakan bahwa nilai perusahaan merupakan suatu proforma manajemen dalam mengelola aktiva perusahaan yang ditunjukkan dengan nilai Tobi's q. Peningkatan nilai perusahaan telah menjadi sasaran utama pihak manajemen perusahaan, karena dengan meningkatnya nilai perusahaan berarti tingkat kemakmuran para pemegang saham semakin baik. Dengan demikian maka dapat dikatakan bahwa, semakin tinggi harga saham maka semakin tinggi pula nilai perusahaan. Oleh karena itu, harga saham yang tinggi telah menjadi perhatian bagi investor karena ada kaitannya dengan peningkatkan kemakmuran bagi pemegang saham.

Untuk mencapai nilai perusahaan yang tinggi maka manajer keuangan akan melakukan tindakan terbaik bagi perusahaan dengan memaksimalkan nilai perusahaan sehingga kemakmuran (kesejahteraan) pemilik atau pemegang saham dapat tercapai (Husnan, 2000:7).

Untuk memaksimalkan nilai perusahaan di masa yang akan datang, maka manajemen keuangan harus mengambil keputusan yang efektif dan efisen terutama berkaitan dengan keputusan investasi, keputusan pembelanjaan serta keputusan dividen (Husnan \& Pujiastuti, 2006). 
Menurut Fama \& French (1998) bahwa setiap keputusan keuangan yang diambil akan mempengaruhi keputusan keuangan lainnya dan berdampak terhadap nilai perusahaan. Oleh karena setiap kebijakan keuangan yang diambil oleh pihak manajemen perusahaan harus mempertimbangkan prinsip-prinsip pembelanjaan yang efektif dan efisien, agar setiap kebijakan yang diambil diusahakan dapat meningkatkan nilai perusahaan.

Perhatian investor terhadap nilai perusahaan menduduki posisi penting karena apabila nilai suatu perusahaan tinggi berarti tingkat kesejahteraan para investor akan meningkat, sehingga dapat menarik para investor untuk menginvestasikan dananya ke perusahaan yang bersangkutan.

Jadi dengan demikian maka dapat dikatakan bahwa, nilai perusahaan yang tinggi dapat meningkatkan kemakmuran bagi para pemegang saham perusahaan. Nilai yang berhubungan dengan saham dapat digunakan dari beberapa sumber. Menurut Jogiyanto (2010) bahwa terdapat beberapa nilai yang berhubungan dengan saham, yaitu nilai buku (book value), nilai pasar (market value), dan nilai intrinsik (intrinsic value).

Nilai perusahaan dapat diukur dengan beberapa cara yaitu : price earning ratio dan price book ratio. Price Earning Ratio yaitu rasio yang mengukur seberapa besar perbandingan antara harga saham perusahaan dengan keuntungan yang diperoleh para pemegang saham (Harga perlembar saham/laba perlembar saham).

\section{Kebijakan Pendanaan.}

Para pengelola keuangan perusahaan dalam mengambil keputusan keuangan harus mempertimbangkan prinsip-prinsip pembelanjaan yang efektif dan efisien. Apabila mengambil kebijakan keuangan yang kurang tepat bisa berdampak pada pencapaian nilai perusahaan, karena nilai perusahaan telah menjadi indikator keberhasilan perusahaan jangka panjang terutama bagi perusahaan yang sudah terdaftar di Bursa Efek Jakarta. Oleh karena itu, setiap emiten akan berusaha untuk memaksimumkan nilai perusahaan agar dapat memakmurkan investornya. cara yang diterapkan adalah dengan menetapkan berbagai kebijakan-kebijakan.

Menurut Moeljadi (2006:60), agar tujuan perusahaan untuk memaksimalkan kekayaan pemegang saham dapat tercapai, maka perlu diambil berbagai kebijakan keuangan (financial decision) yang relevan dan mempunyai pengaruh bagi peningkatan nilai perusahaan.

Kebijakan-kebijakan keuangan meliputi kebijakan investasi (investment decision), kebijakan pendanaan (financing decision), dan kebijakan dividen (dividend decision) (Weston dan Copeland, 1992). Menurut Hanafi (2008:35) bahwa tugas manajer keuangan adalah mengambil keputusan investasi, pendanaan, dan likuiditas dengan tujuan memaksimumkan kemakmuran pemegang saham (nilai saham).

Keputusan keuangan perusahaan yang berkaitan dengan urusan pencarian dana adalah keputusan yang berkaitan dengan keputusan pendanaan atau kebijakan pendanaan yang berorientasi untuk mencari alternatif sumber pendanaan yang dapat digunakan oleh perusahaan dalam rangka meningkatkan nilai perusahaan. Kumar et al (2012) menyatakan bahwa keputusan pendanaan berkaitan dengan keputusan perusahaan dalam mencari dana untuk membiayai investasi dan menentukan komposisi sumber pendanaan, sedangkan Sudana (2011) menyatakan bahwa, keputusan pendanaan berkaitan dengan proses pemilihan sumber dana yang dipakai untuk membelanjai investasi yang 
direncanakan dengan berbagai alternatif sumber dana yang tersedia, sehingga diperoleh suatu kombinasi pembelanjaan yang paling efektif.

Berdasarkan uraian tersebut maka dapat dikatakan bahwa kebijakan pendanaan berkaitan dengan upaya yang dilakukan oleh perusahaan untuk memperoleh sumber dana yang efektif dan efisien, baik yang bersumber dari dalam perusahaan maupun dari luar perusahaan.

Keown, (2011:18) menyatakan bahwa, pembiayaan datang dari dua sumber utama, yaitu: Hutang (kewajiban-kewajiban) dan Ekuitas. Hutang adalah uang yang telah dipinjam dan harus dibayar kembali pada tanggal yang telah ditentukan. Ekuitas menunjukkan investasi pemegang saham dalam perusahaan. Menurut Sudana (2011:20) bahwa dana pinjaman dan saham, merupakan sumber dana yang berasal dari luar perusahaan, sedangkan laba ditahan merupakan sumber dana yang berasal dari dalam perusahaan.

Dalam uraian tersebut diperoleh gambaran bahwa, apabila perusahaan ingin meningkatkan nilai perusahaan maka salah satu alternatif pendanaan yang dapat digunakan adalah dari hutang, sebagaimana dikemukakan oleh Modigliani dan Miller (1963) dalam Hanafi (2008:35) bahwa, pendanaan dapat meningkatkan nilai perusahaan. Di sisi lain, apabila perusahaan menggunakan hutang sebagai sumber pendanaan, berarti menciptakan beban risiko kepada pemegang saham sehingga mempengaruhi return saham (Weston \& Copeland, 1999).

Jadi dengan menggunaan sumber pendanaan dari hutang disamping dapat memberi keuntungan bagi perusahaan tetapi jangan lupa bahwa perusahaan telah memberi beban risiko kepada investor sehingga bisa berdampak pada nilai perusahaan. Namun demikian tentu pihak manajemen perusahaan mempunyai pertimbangan sehingga menjadi dasar dalam menentukan kebijakan pendanaan melalui hutang dari pada menggunaan modal sendiri, dengan alasan pertimbangan biaya emisi, dimana biaya emisi obligasi lebih murah dibandingkan biaya emisi saham baru.

Hal ini disebabkan karena penerbitan saham baru akan menurunkan harga saham lama. Kemudian alasan kedua karena adanya kekhawatiran manajer bahwa penerbitan saham baru dapat ditafsirkan sebagai kabar buruk oleh pemodal. Disisi lain memungkinkan pihak manajemen keuangan lebih mengutamakan sumber pembiayaan internal perusahaan, sebagaimana dikemukakan oleh Myers dalam Kartika (2009:33) bahwa, perusahaan lebih menyukai penggunaan pendanaan dari modal internal, yaitu dana yang berasal dari aliran kas dan laba ditahan, dengan komposisi bahwa urutan penggunaan sumber pendanaan menurut pecking order theory adalah: dana internal, hutang, dan modal sendiri.

Selanjutnya dinyatakan bahwa, dana internal lebih disukai karena memungkinkan perusahaan untuk tidak memperoleh sorotan dari publik akibat penerbitan saham baru (Kartika, 2009:35). Semua hasil keputusan manajer keuangan yang berkaitan dengan keputusan pendanaan, baik yang menggunaan hutang ataupun modal sendiri dapat dilihat laporan keuangan perusahaan yang berada pada neraca sisi pasiva, yaitu berupa utang lancar, utang jangka panjang, dan modal (Sudana, 2011:22).

Untuk mengukur efektifitas penggunaan dana pinjaman perusahaan dapat dilihat dari besarnya nilai Debt to Equity Ratio, yaitu rasio yang menunjukkan perbandingan antara pembiayaan dan pendanaan melalui hutang dengan pendanaan melalui ekuitas (Brigham, 2011:46). Sawir (2001:25) menyatakan bahwa debt to equity ratio adalah Rasio yang 
menggambarkan perbandingan hutang dan ekuitas dalam pendanaan perusahaan dan menunjukkan kemampuan modal sendiri tersebut untuk memenuhi seluruh kewajibannya.

Menurut Sudana (2009:23) bahwa debt to equity ratio adalah rasio yang mengukur proporsi dana yang bersumber dari hutang untuk membiayai aktiva perusahaan. Semakin besar rasio ini menunjukkan porsi penggunaan hutang dalam membiayai investasi pada aktiva semakin besar, yang berarti semakin besar pula risiko keuangan yang dapat dihadapi oleh perusahaan.

Rasio tersebut digunakan dalam penelitian sebagai indikator untuk mengukur keputusan pendanaan yang telah diterapkan oleh perusahaan asuransi yang telah terdaftar di Bursa Efek Jakarta dalam kurun waktu 2008-2014. Kemudian, konsep teori menjadi landasan dari keputusan pendanaan adalah trade off theory, yang menyatakan bahwa perusahaan menukar manfaat pajak dari pendanaan hutang dengan masalah yang ditimbulkan oleh potensi kebangkrutan (Brigham \& Houston, 2011). Teori tersebut menekankan bahwa suatu perusahaan memiliki tingkat hutang yang optimal dan berusaha untuk menyesuaikan tingkat hutang aktualnya ke arah titik optimal, ketika perusahaan tersebut berada pada tingkat utang yang terlalu tinggi atau terlalu rendah.

Jadi esensi teori tersebut yaitu, berusaha menyeimbangkan manfaat dan pengorbanan yang timbul sebagai akibat penggunaan utang. Selagi manfaatnya lebih besar maka tambahan utang masih diperkenankan, namun apabila pengorbanan karena penggunaan utang sudah lebih besar, maka tambahan utang sudah tidak diperbolehkan. Hubungan antara keputusan pendanaan dengan nilai perusahaan telah banyak diamati oleh beberapa peneliti terdahulu, yang menyatakan bahwa keputusan pendanaan berpengaruh positif dan signifian terhadap nilai perusahaan (Rizqia et al., 2013; Afzal \& Rohman, 2012; Wijaya, dkk., 2010).

Demikian juga ditemukan bahwa, kebijakan pendanaan memiliki hubungan positif dengan nilai perusahaan (Gayatri \& Mustanda, 2013:10). Kemudian Suroto (2015) menemukan bahwa keputusan pendanaan berpengaruh negatif terhadap nilai perusahaan, sedangkan Sambora et al., (2014) menemukan bahwa leverage tidak berpengruh terhadap nilai perusahaan.

Keterkaitan antara kebijakan pendanaan dan nilai perusahaan telah diemukakan secara konsep bahwa kebijakan pendanaan merupakan salah satu faktor yang berpengaruh terhadap nilai perusahaan (Sartono, 2008:55). Kemudian Miller (1963) telah menyimpulkan bahwa penggunaan hutang akan meningkatkan nilai perusahaan karena biaya bunga hutang adalah biaya yang mengurangi pajak. Kesimpulan ini telah mendapat dukungan dari peneliti terdahulu (Rizqia et al, 2013; Afzal \& Rohman, 2012; Wijaya dkk., 2010), serta tidak sejalan dengan temuan Suroto (2015) \& Sambora et al., (2014).

Berdasarkan uraian tersebut dengan tetap mengacu pada konsep trade off theory dan pandangan Miller (1963) serta dukungan hasil kajian terdahulu, maka dapat diduga bahwa kebijakan pendanaan mempunyai pengaruh positif dan signifikan dalam meningkatkan nilai perusahaan.

\section{Ukuran Perusahaan.}

Ukuran perusahaan merupakan salah satu faktor yang mempengaruhi nilai perusahaan (Sartono, 2008:55), sedangkan Sawir (2001:54) mengemukakan bahwa ukuran perusahaan dinyatakan sebagai determinan dari struktur keuangan dan hampir 
setiap studi untuk sejumlah alasan yang berbeda. Ada yang menyatakan bahwa ukuran perusahaan dapat menentukan tingkat kemudahan perusahaan memperoleh dana dari pasar modal dan menentukan kekuatan tawar-menawar dalam kontrak keuangan serta ada kemungkinan pengaruh skala dalam biaya dan return membuat perusahaan yang lebih besar dapat memperoleh lebih banyak laba .

Ukuran perusahaan menggambarkan besar kecilnya suatu perusahaan yang dapat dinyatakan dengan total aktiva atau penjualan bersih. Semakin besar jumlah aktiva maupun penjualan, maka semakin besar pula ukuran suatu perusahaan. Moh'd, Perry \& Rimbey (1998) bahwa perusahaan yang berukuran besar akan lebih mudah mengakses pendanaan melalui pasar modal. Kemudahan ini merupakan informasi bagi pengambil keputusan dalam rangka meningkatkan nilai perusahaan. Menurut Ferry \& Jones, 1979 dalam Sawir (2001:54) bahwa, ukuran perusahaan adalah suatu skala dimana dapat diklasifikasikan besar kecilnya perusahaan menurut berbagai cara, antara lain : total aktiva, penjualan, log size, nilai pasar saham, kapitalisasi pasar, dan lain-lain yang semuanya berkorelasi tinggi.

Besarnya ukuran perusahaan dapat menjadi sumber kekuatan perusahaan untuk memaksimalkan nilai perusahaan, namun dalam realitasnya ternyata tidak semua perusahaan yang memiliki ukuran perusahaan yang besar, baik dilihat dari jumlah aktiva yang dimiliki maupun omset penjualan yang sudah diraih dapat meningkatkan nilai perusahaan. Hal ini telah diamati oleh beberapa peneliti terdahulu dan berhasil membuktikan bahwa, ukuran perusahaan merupakan variabel yang paling mempengaruhi nilai perusahaan dalam tiga situasi ekonomi (Hasnawati \& Sawir, 2015). Demikian juga temuan Hansen \& Juniarti (2014); Niresh \& Velnampy (2014); Prasetyorini (2013) ; Sujoko \& Soebiantoro (2007) serta Siallagan \& Mas'ud (2006); Yunita (2011) bahwa ukuran perusahaan berpengaruh positif terhadap nilai perusahaan.

Temuan ini sejalan dengan kesimpulan yang telah dikemukakan oleh Rachmawati \& Triatmoko (2007); Surya \& Rahayuningsih (2012) bahwa, ukuran perusahaan dinyatakan berhubungan positif dan signifian terhadap nilai perusahaan. Temuan yang berbeda dinyatakan oleh Marhamah (2013) bahwa ukuran perusahaan tidak memiliki pengaruh terhadap nilai perusahaan, karena para investor tidak memperhatikan ukuran perusahaan dan lebih memperhatikan informasi lain yang dapat meingkatkan nilai perusahaan, sedangkan Wiyono (2012) membuktikan bahwa nilai perusahaan dipengaruhi secara negatif oleh ukuran perusahaan.

Berdasarkan uraian tersebut maka dapat dikemukakan bahwa, secara konsep dinyatakan ukuran perusahaan merupakan salah satu faktor yang mempengaruhi nilai perusahaan (Sartono, 2008:55). Dilihat dari sisi hasil kajian terdahulu ditemukan oleh beberapa peneliti bahwa ukuran perusahaan mempunyai pengaruh positif terhadap nilai perusahaan, sebalinya ditemukan pula bahwa ukuran perusahaan tidak mempunyai pengaruh terhadap nilai perusahaan. Dengan demikian maka dapat diduga bahwa, ukuran perusahaan mempunyai pengaruh positif dan signifkan dalam meningkatkan nilai perusahaan.

\section{Laba perusahaan.}

Laba merupakan salah satu tujuan yang ingin dicapai oleh perusahaan meskipun sifatnya untuk memenuhi kepentingan jangka pendek. Besarnya laba yang telah dicapai oleh suatu perusahaan pada periode tertentu, telah mencerminkan keberhasilan 
perusahaan dalam menjalankan aktivitas kesehariannya. Kemampuan perusahaan untuk memperoleh laba dapat diukur melalui besar kecilnya profitabilitas yang dihasilkan oleh perusahaan. Profitabilitas menggambarkan sejauhmana perusahaan menghasilkan laba dari penjualan dan investasi perusahaan (Weston \& Copeland, 1992).

Dengan demikian maka dapat dikatakan bahwa, memaksimumkan keuntungan atau laba perusahaan dan memaksimumkan nilai perusahaan merupakan tujuan perusahaan yang saling berkaitan untuk meningkatkan kesejahteraan para pemegang saham. Oleh karena itu, tujuan tersebut memegang peranan penting untuk memelihara kelangsungan hidup perusahaan dimasa yang akan datang.

Memaksimukan keuangan yang dicapai oleh perusahaan dapat menjadi pemicu untuk meningkatkan nilai perusahaan. Dengan meningkatnya keuntungan perusahaan, berarti kegiatan perusahaan dapat dikategorikan berhasil dalam operasinya meskipun untuk kepentingan jangka pendek. Capaian ini dapat memberi informasi bagi calon investor bahwa perusahaan bisa memberikan jaminan pengembalian investasi yang pasti. Oleh kerena itu, pihak manajer perusahaan perlu menerapkan signaling theory.

Teori ini menjelaskan bahwa pemberian sinyal dilakukan oleh manajer untuk mengurangi asimetris informasi dengan cara menerbitkan laporan keuangan perusahaan secara trasparan dan lengkap, sehingga para investor dapat membaca serta melihat kemampuan perusahaan untuk memperoleh laba. Apabila kemampuan perusahaan untuk memperoleh laba yang tinggi dapat menjadi sinyal positif bagi investor sehingga dapat meningkatkan nilai perusahaan.

Hubungan antara kemampuan perusahaan untuk memperoleh laba terhadap peningkatan nilai perusahaan, telah banyak diamati oleh peneliti terdahulu dan menemukan bahwa nilai perusahaan dapat dipengaruhi oleh kemampuan perusahaan untuk memperoleh laba (Hermuningsih, 2013).

Kemudian Ayuningtias (2013); Kusuma dkk., (2012) menemukan bahwa nilai perusahaan dipengaruhi secara positif dan signifikan oleh profitabilitas, serta temuan Dewi \& Wirajaya (2013) menyatakan bahwa profitabilitas berpengaruh terhadap nilai perusahaan. Kemudian Siallagan \& Mas'ud (2006) menemukan bahwa laba perusahan berpengaruh secara positif terhadap nilai perusahaan, hal ini menunjukkan bahwa pelaporan laba perusahaan dapat merefleksikan nilai perusahaan, jika perusahaan mengalami kerugian akan dapat menurunkan nilai perusahaan, Temuan yang berbeda datangnya dari Herawati (2012) yang menyatakan bahwa profitabilitas secara signifikan berpengaruh negatif terhadap nilai perusahaan. Berdasarkan uraian tersebut maka dapat diduga bahwa, laba perusahaan mempunyai pengaruh positif dan signifikan dalam meningkatkan nilai perusahaan.

\section{Risk Based Capital.}

Setiap perusahaan asuransi diwajibkan untuk memenuhi tingkat solvabilitas perusahaan paling sedikit $120 \%$ dari tingkat resiko yang mungkin dapat timbul sebagai akibat dari deviasi dalam mengelola kekayaan dan kewajiban. Tingkat solvabilitas yang dimaksud adalah risk based capital. Risk based capital adalah rasio antara Modal berbanding Resiko. Resiko yang dimaksud adalah klaim yang diajukan oleh seluruh nasabah.

Risk based capital dapat digunakan sebagai alat untuk mendeteksi kebangkrutan (insolvency). Jika perusahaan asuransi memiliki rasio risk based capital dibawah 


\section{JURNAL MEGA AKTIVA}

Email : megaaktiva@febi.umkendari.ac.id

Website : https://megaaktiva.umkendari.ac.id/index.php/Jurnal

ketentuan pemerintah, maka rasio ini menjadi signal yang tidak baik bagi perusahaan asuransi yang bersangkutan. Untuk menentukan besarnya risk based capital maka ada dua komponen yang perlu mendapat perhatian, yaitu solvabilitas dan perhitungan batas tingkat solvabilitas minimum.

Tingkat solvabilitas adalah melihat pada risiko likuiditas yang ditentukan oleh asset dan kewajiban, sedangkan perhitungan batas tingkat solvabilitas minimum mempertimbangkan risiko klaim, yaitu klaim yang sudah terjadi dan klaim masa depan. Dengan perhitungan atau formula yang sama, tentu hal ini akan mengakibatkan rendahnya risk based capital perusahaan yang terkena klaim yang ekstrim dibandingkan dengan perusahaan yang tidak kena dampak.

Hubungan antara risk based capital dengan nilai perusahaan telah diteliti oleh Wulandari (2011) bahwa ada pengaruh yang signifikan tingkat risk based capital terhadap nilai perusahaan, sedangkan Kirmizi (2011) menemukan bahwa tidak ada pengaruh yang signifikan tingkat risk based capital terhadap nilai perusahaan. Dengan demikian maka dapat diduga bahwa risk based capital mempunyai pengaruh yang positif dan signifikan dakam meningkatkan nilai perusahaan.

\section{METODE PENELITIAN}

Penelitian ini menggunakan pendekatan kuantitatif yang bersifat asosiatif, yang menggambarkan hubungan antar dua variabel atau lebih (Sugiyono, 2009:36). Populasi yang diamati adalah semua perusahaan asuransi yang terdaftar di Bursa Efek Jakarta periode tahun 2008 - 2014 sebanyak 11 perusahaan yang diambil dengan teknik purposive sampling yaitu : pemilihan sampel berdasarkan kriteria tertentu (Umar, 2007) antara lain: perusahaan yang diambil adalah semua perusahaan asuransi yang terdaftar di Bursa Efek Indonesia dalam kurung waktu 2008-2014, dan telah mempublikasikan laporan keuangan tahunannya setelah diaudit secara teratur dan menghasilkan laba selama periode tersebut serta secara teratur melaporkan risk based capital dalam laporan keuangan tahunan di Bursa Efek Jakarta. Dengan mengacu pada kriteria tersebut maka terpilih sebanyak 10 perusahaan dengan masa pengamatan selama tujuh tahun, sehingga jumlah sampel dalam penelitian ini adalah 70 sebagai data observasi dalam penelitian ini. Kemudian semua data tersebut adalah sekunder yang diakses dari situs Bursa Efek Jakarta (www.idx.co.id). Data yang digunakan adalah pooling data dimana penyajian data dilakukan secara cross section dan time series.

Fokus kajian ini terbagi atas dua kelompok yaitu variabel Nilai perusahaan dikategorikan sebagai variabel dependen, yang merupakan hasil perbandingan harga perlembar saham dengan laba perlembar saham yang dimiliki oleh perusahaan asuransi (Price Earning Ratio (PER), sedangkan keputusan pendanaan, ukuran perusahaan, laba perusahaan serta risk based capital merupakan variabel independen. Keputusan pendanaan (Debt to Equity Ratio) adalah rasio yang menunjukkan perbandingan antara pembiayaan dan pendanaan melalui hutang dengan pendanaan melalui ekuitas (Brigham dan Houston, 2011) atau Debt to Equity Ratio. Ukuran perusahaan merupakan jumlah aktiva yang dimiliki perusahaan asuransi pada suatu periode tertentu, sedangkan Laba perusahaan merupakan selisih antara penjualan dengan total biaya. Kemudian Risk Based Capital merupakan ratio tingkat solvabilitas yang harus dipenuhi oleh perusahaan berdasarkan ketentuan pemerintah minimal di atas $120 \%$. 
Email : megaaktiva@febi.umkendari.ac.id

Website : https://megaaktiva.umkendari.ac.id/index.php/Jurnal

Untuk membuktikan hipotesis dalam penelitian maka digunakan analisis regresi linier berganda yang penyelesaiannya menggunakan komputer dengan program SPSS. Sebelun melakukan analisis data untuk kebutuhan akhir maka terlebih dahulu data tersebut diuji dengan menggunaan asumsi klasik (uji normalitas, multikolineritas, autokorelasi, dan heteroskedastisitas). Kemudian, sebelum melakukan analisis secara final maka terlebih dahulu data yang tersedia perlu ditransformasi ke dalam log, setelah itu baru dilakukan analisis dengan menggunakan program SPSS.

\section{HASIL DAN PEMBAHASAN}

\section{Analisis Data Penelitian}

Tabel 1. Hasil Estimasi Pengolahan Data Analisis Regresi Linear Berganda

\begin{tabular}{|c|c|c|c|c|}
\hline \multirow[t]{2}{*}{ Model } & \multicolumn{2}{|c|}{ Unstandardized Coeficients } & \multirow[b]{2}{*}{$t$-Hitung } & \multirow[b]{2}{*}{ Significant } \\
\hline & $\mathrm{B}$ & Std. Error & & \\
\hline Constant & 2.213 & 1.198 & 4.170 & 0.069 \\
\hline Keputusan Pendanaan & -0.174 & 0.122 & -1.248 & 0.160 \\
\hline Ukuran Perusahaan & 0.518 & 0.278 & 0.301 & 0.005 \\
\hline Laba Perusahaan & $-0,545$ & 0.162 & -0.728 & 0,001 \\
\hline Risk based capital & $-0,374$ & 0.268 & -1.368 & 0.030 \\
\hline $\mathrm{R}^{2}$ & & 0.205 & & \\
\hline F-Hitung & & 4.179 & & \\
\hline $\begin{array}{l}\text { Significant } \\
\alpha 0.05\end{array}$ & & 0.005 & & \\
\hline
\end{tabular}

Sumber Data : SPSS, 22.00

\section{Pembahasan}

1. Kontribusi Keputusan Pendanaan, Ukuran Perusahaan, Laba Perusahaan serta Risk based capital Terhadap Nilai Perusahaan.

Penelitian ini dimaksudkan untuk mengetahui besarnya kontribusi semua variabel independen (keputusan pendanaan, ukuran perusahaan, laba perusahaan serta risk based capital) secara bersama-sama terhadap peningkatan nilai perusahaan. Berdasarkan hasil penelitian ditemukan bahwa variabel keputusan pendanaan, ukuran perusahaan dan laba perusahaan serta risk based capital secara simultan mempunyai kontribusi yang signifikan dalam meningkatkan nilai perusahaan. Ini berarti untuk meningkatkan nilai perusahaan maka pihak manajer keuangan perlu mengambil keputusan untuk meningkatkan sumber pendanaan perusahaan dengan cara mengambil keputusan pendanaan secara efektif dan efisien.

Selain itu, untuk meningkatkan nilai perusahaan diperlukan adanya peningkatan ukuran perusahaan maupun laba perusahaan serta meingkatkan risk based capital perusahaan. Dengan meningkatnya nilai perusahaan berarti manajemen telah mengambil keputusan secara efektif dan efisien. Hal ini sejalan dengan pandangan Husnan (2007:7) bahwa untuk mencapai nilai perusahaan yang tinggi maka manajer keuangan akan melakukan tindakan terbaik bagi perusahaan dengan memaksimalkan nilai perusahaan sehingga kemakmuran (kesejahteraan) pemilik atau pemegang saham dapat dicapai. 
Menurut Fama \& French (1998) bahwa setiap keputusan keuangan yang diambil akan mempengaruhi keputusan keuangan lainnya dan berdampak pada nilai perusahaan. Hasil temuan ini sekaligus telah memberikan dukungan terhadap sebagian konsep yang telah dikemukaan oleh Sartono (2008:55) bahwa faktor yang mempengaruhi nilai perusahaan adalah keputusan pendanaan, kebijakan dividen, keputusan investasi, struktur modal, pertumbuhan perusahaan dan laba perusahaan.

\section{Kontribusi Keputusan Pendanaan Terhadap Nilai Perusahaan.}

Hasil penelitian menemukan bahwa, keputusan pendanaan tidak mempunyai pengaruh yang signifikan dalam meningkatkan nilai perusahaan. Ini berarti bahwa, keputusan pendanaan yang telah diambil oleh manajer keuangan perusahaan asuransi yang telah terdaftar di Bursa Efek Jakarta selama periode 2008-2014 tidak memberi kontribusi yang berarti dalam meningkatkan nilai perusahaan.

Temuan ini sekaligus memberi informasi terhadap investor bahwa keputusan pendanaan yang diterapkan oleh perusahaan asuransi dalam kurun waktu tersebut, lebih berorientasi pada upaya pemenuhan kebutuhan dana untuk membelanjai aktivanya dengan mengunakan modal sendiri (internal financing), baik yang berasal dari laba ditahan maupun modal saham dari pada menggunakan hutang.

Jika kebijakan ini benar-benar telah menjadi pertimbangan manajer dalam mengambil keputusan pendanaan, berarti manajer kurang berani mengambil beban risiko. Sebagaimana dikemukakan oleh Weston \& Copeland (1999) bahwa, apabila perusahaan menggunakan hutang sebagai sumber pendanaan, berarti menciptakan beban risiko kepada pemegang saham sehingga mempengaruhi return saham.

Kebijakan yang mengutamakan sumber pembiayaan internal, berarti telah memberikan dukungan atas pandangan Myers dalam Kartika (2009:33) bahwa, perusahaan lebih menyukai penggunaan pendanaan dari modal internal, yaitu dana yang berasal dari aliran kas dan laba ditahan, dengan komposisi bahwa urutan penggunaan sumber pendanaan menurut pecking order theory adalah dana internal, hutang dan modal sendiri.

Kemudian Kartika (2009:33) menyatakan bahwa, dana internal lebih disukai karena kemungkinan perusahaan untuk tidak memperoleh sorotan dari publik akibat penerbitan saham baru. Hasil penelitian ini menolak konsep trade off theory yang menyatakan bahwa suatu perusahaan memiliki tingkat hutang yang optimal dan berusaha untuk menyesuaikan tingkat utang aktualnya kearah titik optimal. Menurut Brigham \& Houston (2011), trade off theory menyatakan bahwa perusahaan menukar pajak dari pendanaan hutang dengan masalah yang ditimbulkan oleh potensi kebangkrutan.

Temuan ini telah memberikan dukungan kepada Suroto (2015) yang menyatakan bahwa keputusan pendanaan berpengaruh negatif terhadap nilai perusahaan dan tingkat leverage tidak berpengaruh terhadap nilai perusahaan. Kemudian hasil temuan ini sekaligus menolak temuan yang menyatakan bahwa, keputusan pendaan mempunyai pengaruh yang signifikan dalam meningkatkan nilai perusahaan (Rizqia et al, 2013; Gayatri \& Mustanda, 2013; Afzal \& Rohman, 2012; Wijaya $d k k ., 2010)$.

\section{Kontribusi Ukuran Perusahaan Terhadap Nilai Perusahaan.}

Hasil penelitian menemukan bahwa ukuran perusahaan mempunyai kontribusi yang positif dan signifikan dalam meningkatkan nilai perusahaan. Ini berarti bahwa untuk 
meningkatkan nilai perusahaan maka diperlukan adanya peningkatan ukuran perusahaan melalui peningkatan jumlah asset yang digunakan oleh perusahaan.

Menurut Moh'd, Perry \& Rimbey (1998) bahwa perusahaan yang berukuran besar akan lebih mudah mengakses pendanaan melalui pasar modal. Kemudahan untuk mengakses pendanaan merupakan informasi yang berharga bagi pengambil keputusan dalam rangka meningkatkan nilai perusahaan.

Temuan ini sekaligus telah memberikan dukungan terhadap konsep yang dikumukakan oleh Sartono (2008:55) bahwa, ukuran perusahaan merupakan salah satu faktor yang mempengaruhi nilai perusahaan. Ukuran perusahaan adalah semua jumlah dana yang tertanam dalam aktiva yang dimiliki oleh perusahaan asuransi pada periode tertentu, yang diukur dengan nilai rupiah.

Hasil penelitian ini ikut memperkuat konsep signaling theory yang menyatakan bahwa ukuran perusahaan memiliki pengaruh positif terhadap nilai perusahaan. Kondisi ini mencerminkan bahwa para investor cukup memberi perhatian kepada ukuran perusahaan dalam rangka meningkatkan nilai perusahaan.

Hasil penelitian ini telah memberikan dukungan kepada para peneliti terdahulu, yang juga telah membuktikan bahwa ukuran perusahaan mempunyai kontribusi yang positif dan signifikan dalam meningkatkan nilai perusahaan (Hasnawati \& Sawir, 2015; Hansen \& Juniarti, 2014; Niresh \& Velnampy, 2014; Prasetyorini, 2013; Sujoko \& Soebiantoro, 2007; Siallagan \& Mas'ud, 2006; serta Yunita, 2011; Rachmawati \& Triatmoko, 2007; serta Surya \& Rahayuningsih, 2012).

Kemudian penelitian ini sekaligus menolak hasil temuan yang menyatakan bahwa ukuran perusahaan tidak memiliki pengaruh terhadap nilai perusahaan, karena para investor tidak memperhatikan ukuran perusahaan (Marhamah, 2013). Demikian juga menolak hasil temuan Wiyono (2012) menemukan bahwa nilai perusahaan dipengaruhi secara negatif oleh ukuran perusahaan.

\section{Kontribusi Laba Perusahaan Terhadap Nilai Perusahaan.}

Bertitik tolak dari hasil analisis ditemukan bahwa laba perusahaan mempunyai kontribusi yang positif dan signifikan dalam meningkatkan nilai perusahaan. Hasil penelitian ini mengandung makna bahwa untuk meningkatkan nilai perusahaan maka manajer keuangan perusahaan harus dapat meningkatkan laba perusahaan, meskipun laba bagi perusahaan merupakan tujuan yang bersifat jangka pendek dan tidak dapat dipisahkan dengan nilai perusahaan yang bersifat jangka panjang.

Temuan ini dapat memberi informasi bagi investor bahwa perusahaan bisa memberikan jaminan pengembalian investasi yang pasti. Dengan demikian maka dapat dikatakan bahwa, manajer keuangan perusahaan asuransi yang telah terdaftar di Bursa Efek Jakarta dalam kurun waktu 2008-2014 telah menerapkan signaling theory.

Dimana teori tersebut menjelaskan bahwa pemberian sinyal yang dilakukan oleh manajer untuk mengurangi asimetris informasi dengan cara menerbitkan laporan keuangan perusahaan secara transparan dan lengkap, sehingga para investor dapat membaca dan mengetahui kemampuan perusahaan untuk memperoleh laba. Apabila kemampuan perusahaan untuk mendapatkan laba yang tinggi dapat menjadi sinyal positif bagi investor sehingga nilai perusahaan menjadi meningkat.

Hasil penelitian ini dinyatakan sejalan dengan temuan Hermuningshi (2013) yang menyatakan bahwa nilai perusahaan dapat dipengaruhi oleh kemampuan perusahaan 
untuk memperoleh laba, dan Siallagan \& Mas'ud (2006) menyatakan bahwa laba perusahan berpengaruh secara positif terhadap nilai perusahaan.

Demikian juga telah dibuktikan oleh Ayuningtias (2013); Kusuma dkk., (2012) bahwa nilai perusahaan dipengaruhi secara positif dan signifikan oleh profitabilitas, serta temuan Dewi \& Wirajaya (2013) bahwa profitabilitas berpengaruh terhadap nilai perusahaan. Temuan ini nampaknya bertentangan dengan hasil kajian Herawati (2012) yang menemukan bahwa profitabilitas secara signifikan berpengaruh negatif terhadap nilai perusahaan.

\section{Kontribusi Risk base capital Terhadap Nilai Perusahaan.}

Hasil penelitian menemukan bahwa risk based capital mempunyai pengaruh yang signifikan dalam meningkatkan nilai perusahaan. Artinya bahwa untuk meningkatkan nilai perusahaan maka diperlukan adanya peningakatan risk based capital. Temuan ini menunjukkan bahwa kondisi perusahaan asuransi yang telah terdaftar di Bursa Efek Jakarta dalam kurun waktu 2008-2014 berada dalam posisi aman, karena risk based capital yang telah dicapai oleh perusahaan dapat meningkatkan nilai perusahaan. Ini merupakan sinyal bagi investor bahwa posisi perusahaan dalam kondisi yang baik.

Hasil temuan ini telah memberikan dukungan kepada peneliti terdahulu bahwa, ada pengaruh yang signifikan tingkat risk based capital terhadap nilai perusahaan (Wulandari, 2011). Temuan ini nampaknya tidak sejalan dengan Kirmizi (2011) bahwa tidak ada pengaruh yang signifikan tingkat risk based capital terhadap nilai perusahaan.

\section{KESIMPULAN}

Keputusan keuangan, ukuran perusahaan dan laba perusahaan serta risk based capital secara kolektif atau secara bersama-sama mempunyai pengaruh yang signifikan dalam meningkatkan nilai perusahaan. Keputusan pendanaan ditemukan tidak mempunyai pengaruh yang signifikan dalam meningkatkan nilai perusahaan. Ditemukan pula bahwa ukuran perusahaan mempunyai pengaruh yang positif dan signifikan dalam meningkatkan nilai perusahaan. Nilai perusahaan dapat ditingkatkan melalui peningkatan laba perusahaan, karena ditemukan dalam penelitian bahwa laba perusahaan mempunyai pengaruh yang signifikan dalam meningkatkan nilai perusahaan. Temuan lain bahwa, risk based capital ternyata mempunyai pengaruh yang positif dan signifikan dalam meningkatkan nilai perusahaan. Artinya bahwa, perusahaan asuransi yang telah terdaftar di Bursa Efek Jakarta dalam kurun waktu 2008-2014 yang memberikan jaminan keamanan sehingga para invertor memperoleh sinyal bahwa kondisi perusahaan masih dalam keadaan yang baik.

\section{DAFTAR PUSTAKA}

Afzal., Rohman, 2012. Pengaruh Keputusan Investasi, Keputusan Pendanaan \& Kebijakan Dividen Terhadap Nilai Perusahaan. Dipenegoro Journal of Accounting. Vol.1, No. 2, hal. 09.

Ayuningtias, Dwi. 2013. Pengaruh Profitabilitas Terhadap Nilai Perusahaan: Kebijakan Dividen dan Kesempatan Investasi sebagai Variabel Antara. Jurnal Ilmu dan Riset Akuntansi, Vol.1 (1), hal. 37-57. 


$\int \mid$\begin{tabular}{c} 
JURNAL MEGA AKTIVA \\
Email : megaaktiva@febi.umkendari.ac.id \\
Website $:$ https://megaaktiva.umkendari.ac.id/index.php/Jurnal \\
\hline
\end{tabular}

Arifin, Ali. 2004. Membaca Saham. Yogyakarta: Andi.

Brigham, Eugene F., Houston, Joel F., 2011. Dasar-Dasar Manajemen Keuangan Buku 1. Ali Bahasa: Ali Akbar Yulianto. Salemba Empat. Jakarta.

Brigham, E.F., Gapenski, L.C., Daves, P.R., 2006. Intermedite Financial Management $9^{\text {th }}$.

Dwi, Ayu Sri Mahatma \& Ary Wirajaya. 2013. Pengaruh Struktur Modal, Profitabilitas, \& Ukuran Perusahaan pada Nilai Perusahaan. E-Jurnal Akuntansi Universitas Udayana. Vol. 4. No.2; 358-372.

Rachmawati, Andri., Triatmoko, Hanung, 2007. Analisis Faktor-Faktor yang mempengaruhi Kualitas Laba dan Nilai Perusahaan. Makalah di sampaikan dalam Simposium Nasional Akuntansi 10. Makassar, 26-28 Juli.

Brigham, Eugene, F , and Houston, Joel F., 2011. Dasar-Dasar Manajemen Keuangan. Edisi Ke Sebelas Buku 2. Salemba Empat, Jakarta.

---------, L. C. Gapenski. 1996. Intermediate Financial Management. The Dryden Press. Florida.

Fama, Eugene F., French, K.R. 1998. Taxes, Financing Decisions, and Firm Value dalam The Journal of Finance 53 (3), pp: 819-843.

Hanafi, Mahmud. 2008. Manajemen Keuangan. Edisi Pertama. Yogyakarta: BPFE Yogyakarta.

Hasnawati, Sri, Sawir, Agnes. 2015. Keputusan Keuangan, Ukuran Perusahaan, Struktur Kepemilikan \& Nilai Perusahaan Publik di Indonesia. JM, Vol. 17, No. 1, Maret 2015, 65-75.

Herawati, Titin. 2012. Pengaruh Kebijakan Dividen, Kebijakan Hutang dan Profitabilitas Terhadap Nillai Perusahaan. Jurnal Universitas Negeri Malang.

Husnan, Suad dan Enny Pudjiastuti. (2006). Dasar-dasar Manajemen Keuangan, Edisi Kelima. UPP STIM YKPN.

--------, 2000. Teori Portofolio \& Analisis Sekuritas. AMP YKPN. Yogyakarta.

---------, 1997. Manajemen Keuangan Teori \& Penerapan Keputusan Jangka Panjang. BPFE-Yogyakarta.

Hermuningsih, Sri. 2013. Pengaruh Profitabilitas, Growth Opportunity, Struktur Modal Terhadap Nilai Perusahaan pada Perusahaan Publik di Indonesia. Jurnal Buletin Ekonomi Moneter dan Perbankan, hal. 127-148.

Jogiyanto, 2010. Teori Portofolio and Analisis Investasi. Edisi Ketujuh: BPFE, Yogyakarta.

Kartika, 2009. Pasar Modal Indonesia. Media Soft Indonesia, Jakarta.

Keown, Arthur J., John D Martin et al. 2011. Manajemen Keuangan: Prinsip dan Penerapan. Terjemahan oleh Markus Prihminto Widodo, Jilid 1, Edisi Kesepuluh, PT. Indeks, Jakarta.

Kusuma, Ginanjar Indra, Suhadak., Zainal Arifin. 2012. Analisis Pengaruh Profitabilitas dan Tingkat Pertumbuhan terhadap Struktur Modal dan Nilai Perusahaan (Studi pada Perusahaan Real Estate and Property yang terdaftar di Bursa Efek Jakarta (BEI) Periode 2007-2011). Jurnal Fakultas Ilmu Administrasi Universitas Brawijaya, Malang.

Kumar, S., Anjum, B., Nayyar, S. 2012. Financing Decisions : Studi of Pharmaceutical Companies of India. International Journal of Marketing, Financing Services \& Management Research, 1 (1), pp: 14-28. 
Lindenberg, E.B., Ross, 1981. Tobin's q Ratio \& Industrial Organization. Journal of Business, 54 (1), 1-32.

Marhamah, 2013. Pengaruh Manajemen Laba, Ukuran Perusahaan Terhadap Corporate Social Responsibility (CSR) dan Nilai Perusahaan pada Perusahaan Manufaktur yang terdaftar di Bursa Efek Indonesia Tahun 2007-2010. Jurnal STIE Semarang. Vol. 5 No. 3.

Moeljadi, 2006. Manajemen Keuangan I: Pendekatan Kuantitatif dan Kualitatif. Edisi Pertama. Bayumedia Publishing, Malang.

Modigliani, F., Miller, M, 1963. Taxes and The Cost of Capital: A Correction. American Economic Review, 53 (3), 433-443.

Moh'd, M.A., Perry, L.,G., Rimbey, J.,N., (1998). The Impact of Ownership Structure on Corporation Debt Policy: A Time-series Cross-sectional Analysis. The Financial Review, 33, 85-98.

Nireshh, J., Aloy., T. Velnampy. 2014. Firm Size and Profitability: A Studi of Listed Manufacturing Firms in Sri Langka. Internatinal Journal of Business and Management, Vol. 9 (4): ha. 57-64.

Prasetyorini. Bhekti Fitri. 2013. Pengaruh Ukuran Perusahaan, Leverage, Price Earning Ratio dan Profitabilitas Terhadap Nilai Perusahaan. Jurnal Ilmu Manajemen. Volume 1 Nomor 1 Januari 2013.

Sambora, Mareta Nurjin, Siti Ragil Handayani., Sri Mangesti Rahayu. 2014. Pengaruh Leverage, \& Profitabilitas Teradap Nilai Perusahaan (Studi pada Perusahaan Food and Beyerages yang terdaftar di BEI Periode Tahun 2009-2012. Jurnal Administrasi Bisnis. Vol. 8, No. 1.

Sartono, Agus, 2008. Manajemen Keuangan Teori dan Aplikasi. Yogyakarta: BPFE, Yogyakarta.

Sawir, Agnes, 2001. Analisis Kinerja Keuangan dan Perencanaan Keuangan Perusahaan. Penerbit: PT.Gramedia Pustaka Utama, Jakarta.

Siallagan, Hamonangan., Machfoed, Mas'ud. 2006. Mekanisme Corporate Governance, Kualitas Laba dan Nilai Perusahaan. SNA IX: Ikatan Akuntan Indonesia.

Sudana, I Made, 2011. Manajemen Keuangan Perusahaan: Teori dan Praktik. Penerbit Erlangga, Jakarta.

Sudana, I Made. 2009. Manajemen Keungan: Teori dan Praktek. Airlangga University. Surabaya.

Sujoko \& Ugy Soebiantoro, 2007. Pengaruh Struktur Kepemilikan Saham, Leverage, faktor Intern \& Fator Estern Terhadap Nilai Perusahaan (Studi Empirik pada Perusahaan Manufaktur \& Non Manufaktur di Bursa Efek Jakarta). Jurusan Ekonomi Manajemen, Fakultas Eonomi Universitas Kristen Petra.

Sugiyo, 2009. Metode Penelitian Kuantitatif, Kualitatif dan $R \& D$. Alfabeta, Bandung.

Surya, Dennys \& Deasy Ariyanty Rahayuningsih. 2012. Faktor-Faktor yang Mempengaruhi Kebijakan Hutang Perusahaan Non Keuangan yang terdaftar dalam Bursa Efek Indonesia. Jurnal Bisnis dan Akuntansi, Vol. 14 (3): hal. 213-225.

Suroto, 2015. Pengaruh Keputusan Investasi, Keputusan Pendanaan \& Keputusan Dividen Terhadap Nilai Perusahaan (Srudi Empiris pada Perusahaan LQ-45 yang terdaftar di Bursa Efek Indonesia Periode Februari 2010-2015). Serat Acitya-Jurnal Ilmiah UNTAG, ISSN: 2302-2752, Vol. 4 No.3. Semarang. 


\section{JURNAL MEGA AKTIVA}

Email : megaaktiva@febi.umkendari.ac.id

Website : https://megaaktiva.umkendari.ac.id/index.php/Jurnal

Rizqi, Dwita A., Aisjah, S., Sumiati. 2013. Effect of Managerial Ownership, Financial Leverage, Profitability, Firm Size, \& Invesment Opportunity on Dividen Policy and Firm Value. Research Journal of Finance and Accounting, 41 (11), pp. 120-130.

Tandelilin, Eduardus. 2010. Analisis Investasi dan Manajemen Portfolio. Edisi; Pertama: BPFE, Yogyakarta.

Umar, Husein. 2005. Metode Penelitian: Untuk Skripsi \& Tesis Bisnis. Edisi Baru, Cetakan Pertama. PT. Raja Grafindo Persada. Jakarta.

Yunita, Indah. 2011. Analisis Kebijakan, Profitabilitas, Kebijakan Hutang, Kebijakan Dividen, Size dan Mekanisme Good Corporate Governance Terhadap Nilai Perusahaan (Studi Kasus pada Perusahaan Manufaktur yang terdaftar di Bursa Efek Indonesia Periode 2005-2010). Tesis. Universitas Dipenegoro. Semarang.

Weston, J.F dan Copeland, Thomas E., (1992). Managerial Finance, Edisi kesembilan, The Dryden Press, Harcourt Brace Jovanovic College Publisher, USA, Canada, Tokyo, etc.

Weston, J., Fred \& Thomas E. Copeland. 1999. Manajemen Keuangan. Edisi 8, Jilid 1. Erlangga. Jakarta.

Wiyono, Lany Indriana. 2012. Pengaruh Struktur Kepemilikan, Kebijakan Dividend dan Ukuran Perusahaan terhadap Nilai Perusahaan pada Industri Manufaktur yang terdaftar di BEI Periode 2009-2011. Jurnal Fakultas Bisnis Universitas Katolik Widya Mandala, Surabaya.

Wijaya, Wibowo, 2010. Pengaruh Keputusan Investasi, Keputusan Pendanaan \& Kebijakan Dividen Terhadap Nilai Perusahaan. Simposium Nasional Akuntansi 13. Purwakerto. 